\title{
The influence of fat and hemicellulose on methane production and energy utilization in lactating Jersey cattle ${ }^{1}$
}

\author{
O. R. Drehmel, ${ }^{*}$ T. M. Brown-Brandl, $†$ J. V. Judy, ${ }^{*}$ S. C. Fernando, ${ }^{*}$ P. S. Miller, ${ }^{*}$ K. E. Hales, $\dagger$ \\ and P. J. Kononoff*2 \\ *Department of Animal Science, University of Nebraska-Lincoln, Lincoln 68583 \\ †USDA, Agricultural Research Service, US Meat Animal Research Center, Clay Center, NE 68933
}

\begin{abstract}
Feeding fat to lactating dairy cows may reduce methane production. Relative to cellulose, fermentation of hemicellulose is believed to result in less methane; however, these factors have not been studied simultaneously. Eight multiparous, lactating Jersey cows averaging $( \pm \mathrm{SD}) 98 \pm 30.8 \mathrm{~d}$ in milk and body weight of $439.3 \pm 56.7 \mathrm{~kg}$ were used in a twice-replicated $4 \times 4$ Latin square to determine the effects of fat and hemicellulose on energy utilization and methane production using a headbox-type indirect calorimetry method. To manipulate the concentration of fat, porcine tallow was included at either 0 or $2 \%$ of the diet dry matter. The concentration of hemicellulose was adjusted by manipulating the inclusion rate of corn silage, alfalfa hay, and soybean hulls resulting in either 11.3 or $12.7 \%$ hemicellulose (dry matter basis). The resulting factorial arrangement of treatments were low fat low hemicellulose (LFLH), low fat high hemicellulose (LFHH), high fat low hemicellulose (HFLH), and high fat high hemicellulose (HFHH). Neither fat nor hemicellulose affected dry matter intake, averaging $16.2 \pm 1.18 \mathrm{~kg} / \mathrm{d}$ across treatments. Likewise, treatments did not affect milk production, averaging $23.0 \pm 1.72 \mathrm{~kg} / \mathrm{d}$, or energy-corrected milk, averaging $30.1 \pm 2.41 \mathrm{~kg} / \mathrm{d}$. The inclusion of fat tended to reduce methane produced per kilogram of dry matter intake from 24.9 to $23.1 \pm 1.59$ $\mathrm{L} / \mathrm{kg}$, whereas hemicellulose had no effect. Increasing hemicellulose increased neutral detergent fiber (NDF) digestibility from 43.0 to $51.1 \pm 2.35 \%$. Similarly, increasing hemicellulose concentration increased total intake of digestible NDF from 6.62 to $8.42 \pm 0.89 \mathrm{~kg} / \mathrm{d}$, whereas fat had no effect. Methane per unit of digested
\end{abstract}

\footnotetext{
Received September 12, 2017.

Accepted April 21, 2018.

${ }^{1}$ Mention of trade names or commercial products in this article is solely for the purpose of providing specific information and does not imply recommendation or endorsement by the USDA. USDA is an equal opportunity provider and employer.

${ }^{2}$ Corresponding author: pkononoff2@unl.edu
}

NDF tended to decrease from 64.8 to $49.2 \pm 9.60 \mathrm{~L} /$ $\mathrm{kg}$ with increasing hemicellulose, whereas fat had no effect. An interaction between hemicellulose and fat content on net energy balance (milk plus tissue energy) was observed. Specifically, increasing hemicellulose in low-fat diets tended to increase net energy balance, but this was not observed in high-fat diets. These results confirm that methane production may be reduced with the inclusion of fat, whereas energy utilization of lactating dairy cows is improved by increasing hemicellulose in low-fat diets.

Key words: energy utilization, fat, hemicellulose, indirect calorimetry, methane

\section{INTRODUCTION}

Methane is a potent greenhouse gas that contributes to global warming (Benchaar et al., 2001). Methanogenesis, the formation of methane, is a vital biological pathway in ruminants because it is the main hydrogen sink in the rumen, yet it is also characterized as an energetic loss for cattle that ranges from 2 to $12 \%$ gross energy (GE) intake (Cabezas-Garcia et al., 2017). Because cattle produce more methane than any other livestock species, a need exists to develop effective methods to reduce methane production in lactating dairy cattle. A worldwide focus has been placed on developing mitigation strategies for both dairy and beef industries. In 2009, the US dairy industry, represented by the Innovation Center for US Dairy, committed to a voluntary goal to reduce greenhouse gas emissions by 25\% by 2020 (Innovation Center for US Dairy, 2014).

One method to reduce methane production in dairy cattle is through manipulation of the ruminal microbial community via feed ingredients included in the diet. For example, the addition of fat is known to increase GE density of the diet, but also reduce methane production (Beauchemin et al., 2008). When consumed by cattle, fibrous by-products are also believed to result in less methane per unit of digested DM compared with other forages (Johnson and Johnson, 1995). Knapp et 
al. (2014) suggested this is because these feeds are high in hemicellulose and that the digestion of hemicellulose produces $37 \%$ less methane than that of digested cellulose (Moe and Tyrrell, 1979). The hemicellulose content of feeds can be estimated by the difference between NDF and ADF (Goering and Van Soest, 1970). Based on this method, estimates of the hemicellulose content of dry distillers grains and solubles (DDGS) is approximately 19\% (NRC, 2001). Brewers grains contain approximately $25 \%$ hemicellulose, whereas corn gluten meal and citrus pulp contain approximately 3 and $2 \%$, respectively. The hemicellulose content of forages such as alfalfa hay is approximately $9 \%$, whereas grass hay and corn silage contain approximately 25 and $17 \%$ hemicellulose, respectively (NRC, 2001). Given that the hemicellulose content of feeds vary, it is likely that dietary manipulation may be an effective way to reduce methane production in dairy cattle. Recently Benchaar et al. (2013) and Foth et al. (2015) observed that dairy cattle produce $14 \mathrm{~g} / \mathrm{d}$ or $7 \%$ less methane when they consume diets containing 30\% DDGS compared with a traditional corn and soybean meal diet. Thus, a need exists to evaluate how methane production may be further reduced when cattle are consuming diets containing a high proportion of DDGS. The objective of our study was to determine the effects of feeding different concentrations of fat and hemicellulose on methane production and energy utilization in lactating Jersey cows consuming diets containing high concentrations of DDGS. We hypothesized that diets containing more fat and hemicellulose would result in a reduction of methane production and may also positively affect energy balance.

\section{MATERIALS AND METHODS}

Eight multiparous Jersey cows averaging $98 \pm 30.8$ DIM and $439.3 \pm 56.7 \mathrm{~kg}$ of BW at the beginning of the experiment were used for this study. All cows were housed in a temperature-controlled barn at the Dairy Metabolism Facility at the Animal Science Complex at the University of Nebraska-Lincoln and milked at 0700 and $1800 \mathrm{~h}$ in individual tiestalls equipped with rubber mats. All animal care and experimental procedures were approved by the University of Nebraska-Lincoln Animal Care and Use Committee. At the conclusion of the last experimental period, all cows were less than 90 d pregnant; thus, no energetic adjustments were made for conceptus growth. This was because energy to fetus is very minimal less than $90 \mathrm{~d}$ pregnant.

The experimental design was a twice-replicated 4 $\times 4$ Latin square. Cows were randomly assigned to 1 of the 4 dietary treatments, low fat low hemicellulose
(LFLH), low fat high hemicellulose (LFHH), high fat low hemicellulose (HFLH), or high fat high hemicellulose (HFHH), according to Kononoff and Hanford (2006). Treatments were designed as a $2 \times 2$ factorial arrangement of treatments. Animals were blocked into each square by milk production $(\mathrm{kg} / \mathrm{d})$. Treatments alternated over 4 experimental periods and measurements were collected on each animal consuming each treatment within the same period. The study was conducted with a total of 4 experimental periods, each being $35 \mathrm{~d}$ in duration. Each period included $28 \mathrm{~d}$ for ab libitum diet adaptation, targeting about $5 \%$ refusals during that time, followed by $7 \mathrm{~d}$ of collection with 4 d of $95 \%$ ad libitum feeding to reduce the amount of refusals.

The 4 diets were formulated with treatments containing different concentrations of fat and hemicellulose (Table 1). Manipulation of hemicellulose was achieved by varying the concentrations of corn silage, alfalfa hay, and ground soybean hulls; ground corn also varied between treatments. The fat source used was porcine tallow, which was added to the diet at approximately $2 \% \mathrm{DM}$ in 2 dietary treatments, whereas the other 2 dietary treatments had none. Dried distillers grains with solubles were added to all 4 dietary treatments at a consistent amount of $20.1 \%$ of diet DM. Complete diet compositions and nutrient analysis for all treatments are presented in Table 1. All dietary treatments contained corn silage, alfalfa hay, and a concentrate mixture that was combined as a TMR. The TMR was mixed in a Calan Data Ranger (American Calan Inc., Northwood, NH) and fed once daily at $0900 \mathrm{~h}$ to the cows.

Individual feed ingredients were sampled $(500 \mathrm{~g})$ on the first day of each collection period and frozen at $-20^{\circ} \mathrm{C}$. A subsample was sent to Cumberland Valley Analytical Services Inc. (Hagerstown, MD) for complete nutrient analysis. The DM content of concentrates was determined by drying at $135^{\circ} \mathrm{C}$ (Method 930.15 , AOAC International, 2000). The DM content of forages was determined by a 2-step process, where the first sample is partially dried at $65^{\circ} \mathrm{C}$ for $16 \mathrm{~h}$ (Goering and Van Soest, 1970) and then $105^{\circ} \mathrm{C}$ for $3 \mathrm{~h}$. Additionally, nitrogen (Leco FP-528 N Combustion Analyzer, Leco Corp., St. Joseph, MI), NDF with sodium sulfite (Van Soest et al., 1991) and $\alpha$ amylase, ADF (method 973.18; AOAC International, 2000), acid detergent lignin (Goering and Van Soest, 1970), NFC [100-(\% NDF + \% CP + \% Fat $+\%$ Ash)], sugar (DuBois et al., 1956), starch (Hall, 2009), crude fat (2003.05; AOAC International, 2006), ash (943.05; AOAC International, 2000) and minerals (985.01; AOAC International, 2000) were determined. Total mixed rations were sampled (500 g) on each day 
of each collection period and were frozen at $-20^{\circ} \mathrm{C}$. The samples were then composited by period and treatment. A subsample was sent to Cumberland Valley Analytical Services Inc. for complete nutrient analysis using the same laboratory processes as the individual feed ingredients. The TMR was used to determine particle size according to Heinrichs and Kononoff (2002) using the Penn State particle separator. Each day of the collection period refusals were sampled and frozen at $-20^{\circ} \mathrm{C}$. The samples were composited by period and individual cow. A subsample was sent to Cumberland Valley Analytical Services Inc. for nutrient analysis of DM (AOAC International, 2000), N (Leco FP-528 N Combustion Analyzer, Leco Corp.), NDF with sodium sulfite (Van Soest et al., 1991), starch (Hall, 2009), and ash (943.05; AOAC International, 2000).

Total fecal and urine output was collected from each individual cow during the collection period for 4 consecutive days (Monday to Thursday). A $137 \times 76 \mathrm{~cm}$ rubber mat was placed behind the cow to collect feces. The feces were deposited multiple times a day from the rubber mats into a large garbage container (Rubbermaid, Wooster, $\mathrm{OH}$ ) with a black garbage bag covering the top to reduce nitrogen losses before subsampling. The feces were subsampled (500 g) every day for 4 consecutive days, dried at $60^{\circ} \mathrm{C}$ in a forced-air oven for 48 $\mathrm{h}$, and then composited by cow and period before being ground to pass through a 1-mm screen (Wiley Mill,

Table 1. Chemical composition and analysis of treatments differing in fat and hemicellulose concentration with inclusion of dry distillers grains and solubles (DDGS)

\begin{tabular}{|c|c|c|c|c|}
\hline Item & \multicolumn{4}{|c|}{ Treatment $^{1}$} \\
\hline \multicolumn{5}{|l|}{ Ingredient, $\%$ of DM } \\
\hline Alfalfa hay & 24.9 & 5.71 & 24.9 & 5.7 \\
\hline Dried ground corn & 16.7 & 5.94 & 15.1 & 4.6 \\
\hline Ground soybean hulls & 1.14 & 11.7 & 1.14 & 11.7 \\
\hline Nonenzymatically browned soybean meal $^{2}$ & 1.83 & 1.83 & 1.83 & 1.83 \\
\hline Porcine bloodmeal & 1.37 & 1.37 & 1.37 & 1.37 \\
\hline Porcine tallow & - & - & 1.60 & 1.33 \\
\hline Calcium carbonate & 1.60 & 1.60 & 1.60 & 1.60 \\
\hline Sodium bicarbonate & 0.59 & 0.59 & 0.59 & 0.59 \\
\hline Ca-salts LCFA ${ }^{3}$ & 0.69 & 0.69 & 0.69 & 0.69 \\
\hline Magnesium oxide & 0.18 & 0.18 & 0.18 & 0.18 \\
\hline Hemicellulose, ${ }^{7} \%$ of DM & $11.5(0.76)$ & $13.0(0.78)$ & $11.1(1.52)$ & $12.4(0.90)$ \\
\hline $\mathrm{CP}, \%$ of DM & $18.3(0.61)$ & $18.0(0.90)$ & $18.5(0.74)$ & $17.7(0.43)$ \\
\hline Crude fat, $\%$ of DM & $4.11(0.29)$ & $4.57(0.33)$ & $4.98(0.47)$ & $5.63(0.59)$ \\
\hline $\mathrm{ADF}, \%$ of $\mathrm{DM}$ & $22.9(1.14)$ & $22.4(1.77)$ & $21.9(1.50)$ & $22.2(0.91)$ \\
\hline $\mathrm{NDF}, \%$ of $\mathrm{DM}$ & $34.4(0.91)$ & $35.4(1.36)$ & $32.9(1.12)$ & $34.6(1.08)$ \\
\hline Lignin, $\%$ of DM & $4.29(0.41)$ & $3.15(0.18)$ & $4.44(0.39)$ & $3.34(0.13)$ \\
\hline Ash, $\%$ of DM & $7.37(0.29)$ & $7.12(0.63)$ & $7.74(0.33)$ & $6.88(0.19)$ \\
\hline Starch, \% of DM & $20.2(2.15)$ & $21.4(1.97)$ & $19.3(2.71)$ & $20.7(2.35)$ \\
\hline Gross energy ${ }^{8} \mathrm{cal} / \mathrm{g}$ & $4,410.7(51.2)$ & $4,394.0(59.4)$ & $4,502.0(68.0)$ & $4,452.5(76.1)$ \\
\hline $\mathrm{ME},{ }^{9} \mathrm{Mcal} / \mathrm{kg}$ & 2.60 & 2.60 & 2.67 & 2.67 \\
\hline $\mathrm{NE}_{\mathrm{L}},{ }^{9} \mathrm{Mcal} / \mathrm{kg}$ & 1.68 & 1.68 & 1.72 & 1.72 \\
\hline
\end{tabular}

${ }^{1}$ Treatments: $\mathrm{LFLH}=$ low fat low hemicellulose; LFHH = low fat high hemicellulose; HFLH $=$ high fat low hemicellulose; HFHH $=$ high fat high hemicellulose.

${ }^{2}$ Soypass, LignoTech, Overland Park, KS.

${ }^{3}$ Calcium salts of long-chain fatty acids (LCFA) marketed as Megalac by Church \& Dwight Co. Inc., Princeton, NJ.

${ }^{4}$ Formulated to supply approximately $2,300 \mathrm{mg} / \mathrm{kg} \mathrm{Co}, 25,000 \mathrm{mg} / \mathrm{kg} \mathrm{Cu}, 2,600 \mathrm{mg} / \mathrm{kg} \mathrm{I}, 1,000 \mathrm{mg} / \mathrm{kg} \mathrm{Fe}, 150,000 \mathrm{mg} / \mathrm{kg} \mathrm{Mn}, 820 \mathrm{mg} / \mathrm{kg} \mathrm{Se}$, and $180,000 \mathrm{mg} / \mathrm{kg} \mathrm{Zn}$ in total rations.

${ }^{5}$ Formulated to supply approximately 148,500 IU/d vitamin A, 38,500 IU/d vitamin D, and $902 \mathrm{IU} / \mathrm{d}$ vitamin E in total rations.

${ }^{6}$ Values determined by Cumberland Valley Analytical Services, Hagerstown, MD; values denoted as mean (SD).

${ }^{7}$ Hemicellulose $=\mathrm{NDF}-\mathrm{ADF}$.

${ }^{8}$ Determined from composite samples from experiment and analyzed at the University of Nebraska-Lincoln.

${ }^{9}$ Values formulated from Cornell-Penn-Miner dairy model (Boston et al., 2000). 
Arthur H. Thomas Co., Philadelphia, PA). The ground feces sample were sent to Cumberland Valley Analytical Services Inc. for nutrient analysis of DM (AOAC International, 2000), N (Leco FP-528 N Combustion Analyzer, Leco Corp.), NDF with sodium sulfide (Van Soest et al., 1991), starch (Hall, 2009), and ash (943.05; AOAC International, 2000). Total urine was collected by inserting a 30 French foley catheter into each cow's bladder with a stylus. The balloon was inflated to 50 $\mathrm{mL}$ with physiological saline and Tygon (Saint Gobain, La Defense, Courbevoie, France) tubing drained into a plastic carboy (15 quart) behind the cow. Using the funnel spout of the plastic carboy, urine was deposited into a 55 -L plastic container 4 times a day and was acidified with $50 \mathrm{~mL}$ of $\mathrm{HCl}$ ( $2 \%$ wet basis) before subsampling $(500 \mathrm{~mL})$ and freezing at $-20^{\circ} \mathrm{C}$ every day of the collection period. Prior to analysis, urine was thawed and boiled to remove the water content. To boil the urine, 2 thawed $250-\mathrm{mL}$ bottles of urine were poured into a $600-\mathrm{mL}$ beaker. Fourteen urine-filled beakers were placed into a boiling water bath (Ankom Technology, Macedon, NY) underneath a hood. The water bath was turned on in the morning and off in the afternoon, for approximately $6 \mathrm{~h} / \mathrm{d}$, to reduce the chance of the sample being overheated and burned. After water was boiled away, the remaining dark brown paste was then composited by cow and period. The brown paste was then lyophilized (VirTis Freezemobile 25ES, SP Scientific, Gardiner, NY). Once lyophilized, sample size was reduced using mortar and pestle and then used for analysis. The lyophilized urine samples were analyzed at the University of Nebraska-Lincoln for laboratory-corrected $\mathrm{DM}\left(100^{\circ} \mathrm{C}\right.$ oven for $\left.24 \mathrm{~h}\right), \mathrm{N}$ (Leco FP-528, Leco Corp.), and GE (Parr 6400 Calorimeter, Moline, IL).

Milk production was measured daily and milk samples were collected during both the morning and evening milkings for 5 consecutive days or d 29 to 33 of the entire period. Three tubes were collected each milking $(150 \mathrm{~mL})$; two $50-\mathrm{mL}$ conical tubes were frozen at $-20^{\circ} \mathrm{C}$ and 1 tube was sent to Heart of America DHIA (Kansas City, MO) preserved with 2-bromo-2-nitropropane-1,3 diol. Milk samples were analyzed for fat, protein, lactose, SNF, MUN, and SCC using a Bentley FTS/FCM Infrared Analyzer (Bentley Instruments, Chaska, MN). One of the 2 conical tubes was lyophilized and then composited by cow and period for nutrient analysis. Milk samples were analyzed at the University of Nebraska-Lincoln for laboratory-corrected DM, N, and GE. To determine the DM content of individual feed ingredients, TMR, refusals, feces, and urine samples were dried at $60^{\circ} \mathrm{C}$ in a forced-air oven for $48 \mathrm{~h}$ and then composited by treatment or cow and period. Milk samples were lyophilized to determine DM. Feed ingredients, refusals, and feces were ground as previously described with the feces and for laboratory-corrected DM and GE.

Heat production was determined through the headbox-type indirect calorimeters, described by Foth et al. (2015) and Freetly et al. (2006), that were built at the University of Nebraska-Lincoln. For each cow, a collection period of 2 consecutive 23 -h intervals measured oxygen consumption and carbon dioxide and methane production. The design of the headboxes allowed for feed to be placed in the bottom of the box, and ad libitum access to water was available for the cows from a water bowl placed inside the headbox. Free water intake was measured using DLJGHT garden hose water meter (DLJ Meter, Hackensack, NJ) while each cow was inside the headbox, whereas water from feed was calculated from moisture contents of feed consumed. Within the headbox, temperature and dew point were recorded every minute for a 23 -h interval using a probe (model TRH-100, Pace Scientific Inc., Moorseville, NC) that was connected to a data logger (model XR440, Pace Scientific Inc.). Fifteen minutes before the start of the collection, the doors were closed and motor was turned on. Line pressure was measured using a manometer (item \# 1221-8, United Instruments, Westbury, NY). Barometric pressure of the room was also recoded using a barometer (Chaney Instruments Co., Lake Geneva, WI) and uncorrected for sea level. Total volume of gas in the headbox was measured using a gas meter (model AL425, American Meter, Horsham, PA). From the headbox, continuous amounts of outgoing and incoming air were diverted to 2 different collection bags (61 $\times 61 \mathrm{~cm}$ LAM-JAPCON-NSE, 44 L; PMC, Oak Park, IL) using glass tube rotameters (model 1350E Sho-Rate "50," Brooks Instruments, Hatfield, PA). Collection bags with gas samples inside were analyzed (Emerson $\mathrm{X}$-stream 3-channel analyzer, Solon, $\mathrm{OH}$ ) at 2 locations: the University of Nebraska-Lincoln and at US Meat Animal Research Center according to Nienaber and Maddy (1985). Measurements collected from the $2 \mathrm{~d}$ and both locations were averaged to obtain a combined value. Heat production was estimated through calculation of oxygen consumption, and carbon dioxide and methane production with correction for urinary $\mathrm{N}$ loss according to Brouwer (1965; Equation 1). The gaseous products were reported in liters and the mass of urinary $\mathrm{N}$ in grams. Respiratory quotient was calculated using the ratio of carbon dioxide produced to the oxygen consumed and was not corrected for nitrogen. Volume of methane produced was multiplied by a constant of 9.45 $\mathrm{kcal} / \mathrm{L}$ to estimate the amount of energy formed from the gaseous products. Energy balance was calculated 
for each cow and adjusted for excess $\mathrm{N}$ intake according to Freetly et al. (2006) using the following equations:

Heat production $(\mathbf{H P} ; \mathrm{Mcal} / \mathrm{d})=3.866 \times \mathrm{O}_{2}(\mathrm{~L})$

$$
\begin{aligned}
+1.200 \times & \mathrm{CO}_{2}(\mathrm{~L})-0.518 \times \mathrm{CH}_{4}(\mathrm{~L}) \\
& -1.431 \times \mathrm{N}(\mathrm{g}),
\end{aligned}
$$

$\operatorname{ME}(\mathrm{Mcal} / \mathrm{d})=\mathrm{GE}$ intake $(\mathrm{Mcal} / \mathrm{d})$

- fecal energy (Mcal/d) - urinary energy (Mcal/d)

$$
\text { - methane energy (Mcal/d), }
$$

Recovered energy $(\mathbf{R E} ; \mathrm{Mcal} / \mathrm{d})=\mathrm{ME}-\mathrm{HP}$,

Tissue energy $(\mathbf{T E} ; \mathrm{Mcal} / \mathrm{d})=$

$$
\mathrm{RE} \text { - milk energy (Mcal/d), }
$$

and

Tissue energy in protein $(\mathrm{g} / \mathrm{d})=$

$(\mathrm{N}$ balance, $\mathrm{g} / \mathrm{d}) \times(5.88 \mathrm{~kg}$ of protein $/ \mathrm{kg}$ of $\mathrm{N})$

$$
\times(5.7 \mathrm{Mcal} / \mathrm{kg} \text { of protein }) / 1,000 .
$$

Metabolizable energy for maintenance was found by regression of $\mathrm{RE}$ on $\mathrm{ME}$ and is the $\mathrm{ME}$ at zero $\mathrm{RE}$, as shown in Figure 1. Tissue energy in protein describes the energy used for tissue protein synthesis (Equation $5)$.
Data were analyzed using the MIXED procedure of Version 9.4 of SAS (SAS Institute Inc., Cary, NC). A single factor for treatment was considered a fixed effect. Cow within square was considered as a random effect. Using the LSMEANS option, the least squares means of the treatments were found. The main effects of fat and hemicellulose and the interaction between these 2 factors were tested using the CONTRAST statement of SAS. Significance was declared at $P \leq 0.05$ and tendencies at $0.05<P \leq 0.15$.

\section{RESULTS AND DISCUSSION}

\section{Diet Composition}

The chemical composition of individual feed ingredients and dietary treatments are presented in Tables 4] 1 and 2. As estimated by the difference between NDF and $\mathrm{ADF}$, the hemicellulose concentration was adjusted by manipulating the inclusion rate of corn silage, alfalfa hay, and soybean hulls, resulting in either $11.3 \%$ DM for low-hemicellulose diets or $12.7 \%$ DM for highhemicellulose diets (Table 1). This difference was small but differed in the greatest extent possible to minimize any differences in energy and other nutrient requirements between treatments. Despite not being a direct measure, the difference between ADF and NDF is the most common way of determining hemicellulose for feed ingredients (Goering and Van Soest, 1970). Porcine tallow was included at approximately $2 \%$ DM for high-fat diets and 0\% DM for low-fat diets (Table 1). Other

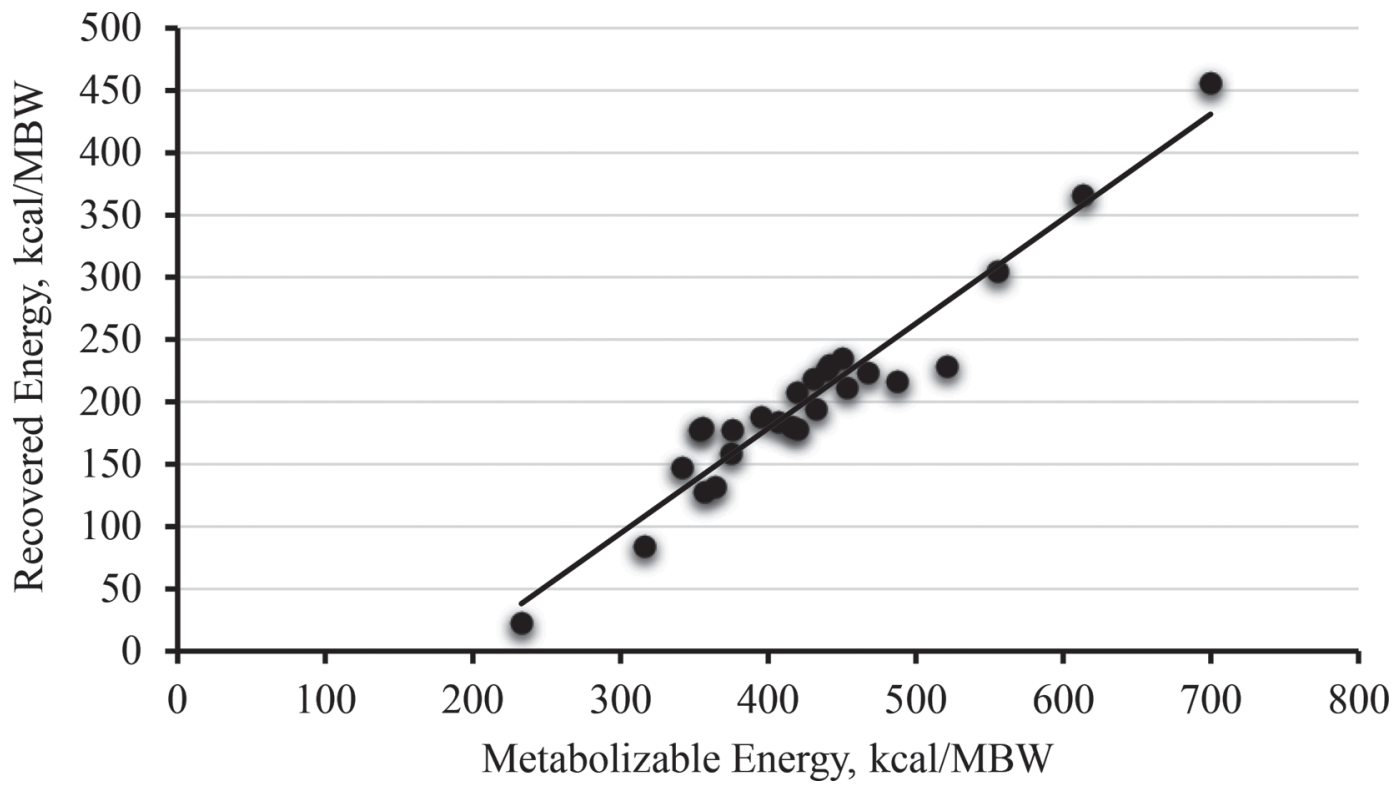

Figure 1. Regression of recovered energy on ME intake in kilocalories per metabolic BW (kcal/MBW; $\left.\mathrm{y}=0.8413 \mathrm{x}-157.8 ; \mathrm{R}^{2}=0.93\right)$. Recovered energy $=0$ at $188 \mathrm{kcal} / \mathrm{MBW}$ and efficiency of converting ME to lactation energy is $84 \%$. 
than ground corn, diets were formulated to have ingredients included at similar inclusion rates (Table 1). All diets included DDGS (E Energy Adams LLC, Adams, $\mathrm{NE}$ ) at $20.1 \% \mathrm{DM}$ of the diet (Table 1 ) and contained $8.07 \pm 0.62 \%$ DM crude fat. The high-fat diets were formulated to have the similar energy content $\left(\mathrm{NE}_{\mathrm{L}}=\right.$ $1.72 \mathrm{Mcal} / \mathrm{kg}$ ) and the low-fat diets were formulated to have similar energy content $\left(\mathrm{NE}_{\mathrm{L}}=1.68 \mathrm{Mcal} / \mathrm{kg}\right)$, as listed in Table 1. Neutral detergent fiber content of the high-hemicellulose treatments was $35.0 \pm 1.22 \%$, which is greater than the low-hemicellulose treatments at 33.7 $\pm 1.02 \%$ (Table 1 ). This was expected because hemicellulose is a cell wall component and NDF is composed of cellulose, hemicellulose, and lignin. Therefore, more hemicellulose $(12.7 \% \mathrm{DM})$ would result in more NDF. Crude fat of the high fat treatments was $5.31 \pm 0.53 \%$, which was higher than the low-fat treatments at $4.34 \pm$ $0.31 \%$ (Table 1). This was also expected because tallow is a fat source and, by design, was only included in the high-fat treatment diets.

Diet particle size was not different between the 2 lowhemicellulose and 2 high-hemicellulose diets, as listed in Table 3. For the LFLH diets, 4.38, 20.6, 64.0, and 11.1\% remained on the $>19.0 \mathrm{~mm}, 8.0 \mathrm{~mm}, 1.18 \mathrm{~mm}$ and pan $(<1.18 \mathrm{~mm})$, respectively, and for the HFLH diets, 3.75 , $19.5,63.8$, and $13.3 \%$ remained. For the LFHH diets, $3.88,34.3,55.6$, and $6.13 \%$ remained on the $>19.0 \mathrm{~mm}$, $8.0 \mathrm{~mm}, 1.18 \mathrm{~mm}$, and pan $(<1.18 \mathrm{~mm})$, respectively, and for the HFHH diets, 2.63, 34.6, 56.6, and $6.00 \%$ remained. According to Heinrichs and Kononoff (2002), it is recommended that the distribution of particles in a ration should include 2 to $8 \%$ of particles remaining on the $>19.0-\mathrm{mm}$ diameter sieve, 30 to $50 \%$ should be retained on the 8.0- and 1.18-mm sieves, and $\leq 20 \%$ on the bottom pan. In the current study, the proportions of particles retained on the 8-mm sieve were lower than recommended, this was especially true for the lowhemicellulose diets. One possible consequence for the deviation from the recommended particle proportions is that cows may not consume enough effective fiber to maintain healthy rumen conditions, which may lead to rumen acidosis (Zebeli et al., 2010). Furthermore, it should be noted that the recommendations of Heinrichs and Kononoff (2002) are without consideration that dairy cow diets can be formulated to contain large proportions of corn milling by-products in replacement of ground corn. In the current study, DDGS were included at $20 \%$ of the diet DM and starch content was low and approximately $20 \%$ across treatments. This concentration of starch is substantially lower than what may be commonly fed in a commercial setting (Chase, 2007) and less likely to cause rumen acidosis (Bradford and Mullins, 2012).

\section{Feed Intake, Milk Production and Composition, Water Intake}

In the first period of the study, 2 cows from the second square were diagnosed with mastitis and were subsequently replaced by 2 new cows, which were used for the remainder of the study; as a consequence, no data from these cows were collected for period 1 and considered missing. Feed intake, milk production and composition, and water intake are listed in Table 4. No interactions $(P \geq 0.21)$ were observed between fat and hemicellulose for any dependent variable tested. Neither fat nor hemicellulose affected DMI $(P \geq 0.25)$, averaging $16.2 \pm 1.18 \mathrm{~kg} / \mathrm{d}$ across all treatments. The high-fat diets were formulated to contain similar energy content and the low-fat diets were also formulated to contain a similar energy content. The lack of difference in DMI may be due to diets being formulated to have the same energy content, as cattle typically eat to a constant energy. The addition of fat increased the dietary energy content and is likely what numerically reduced DMI in the high-fat diets. Similar to the present study, Hales et al. (2017) noted no difference in DMI or GE intake as corn oil increased in a high-concentrate finishing diet fed to growing beef steers. In a meta-analysis by Rabiee et al. (2012), inclusion of tallow in the diet tended to reduce DMI, which is in contrast with the results of the current study. In another study, Beauchemin et al. (2007) observed that DMI was not affected by inclusion of $34 \mathrm{~g} / \mathrm{kg}$ of DM tallow, which this agrees with the current study. In a study by Herrick et al. (2012) on lactating Holstein cows, the authors found that feeding hemicellulose extract did not affect DMI. It is important to note that Herrick et al. (2012) added a hemicellulose extract to the diet, whereas in the current study the hemicellulose content was manipulated through feed formulation. The nutrient requirements of dairy cattle (NRC, 2001) and beef cattle (NASEM, 2016) both recommend that fat should not exceed $7 \%$ of the diet (DM basis) or a reduction in DMI could occur. Therefore, it is not surprising that we did not observe a difference in DMI because of dietary fat manipulation, as the inclusion of fat on a DM basis was much lower than $7 \%$ in the current study.

In the current study, treatments did not affect $(P \geq$ 0.51 ) milk yield, averaging $23.0 \pm 1.72 \mathrm{~kg} / \mathrm{d}$. Inclusion of fat tended $(P=0.15)$ to reduce ECM from 31.0 to $29.2 \pm 2.41 \mathrm{~kg} / \mathrm{d}$, whereas hemicellulose had no effect $(P=0.80)$. In a meta-analysis using multiple breeds of lactating dairy cattle, Rabiee et al. (2012) reported that the inclusion of tallow had no effect on milk yield. Herrick et al. (2012) also reported that inclusion of a hemicellulose extract had no effect on milk yield in 
DREHMEL ET AL.

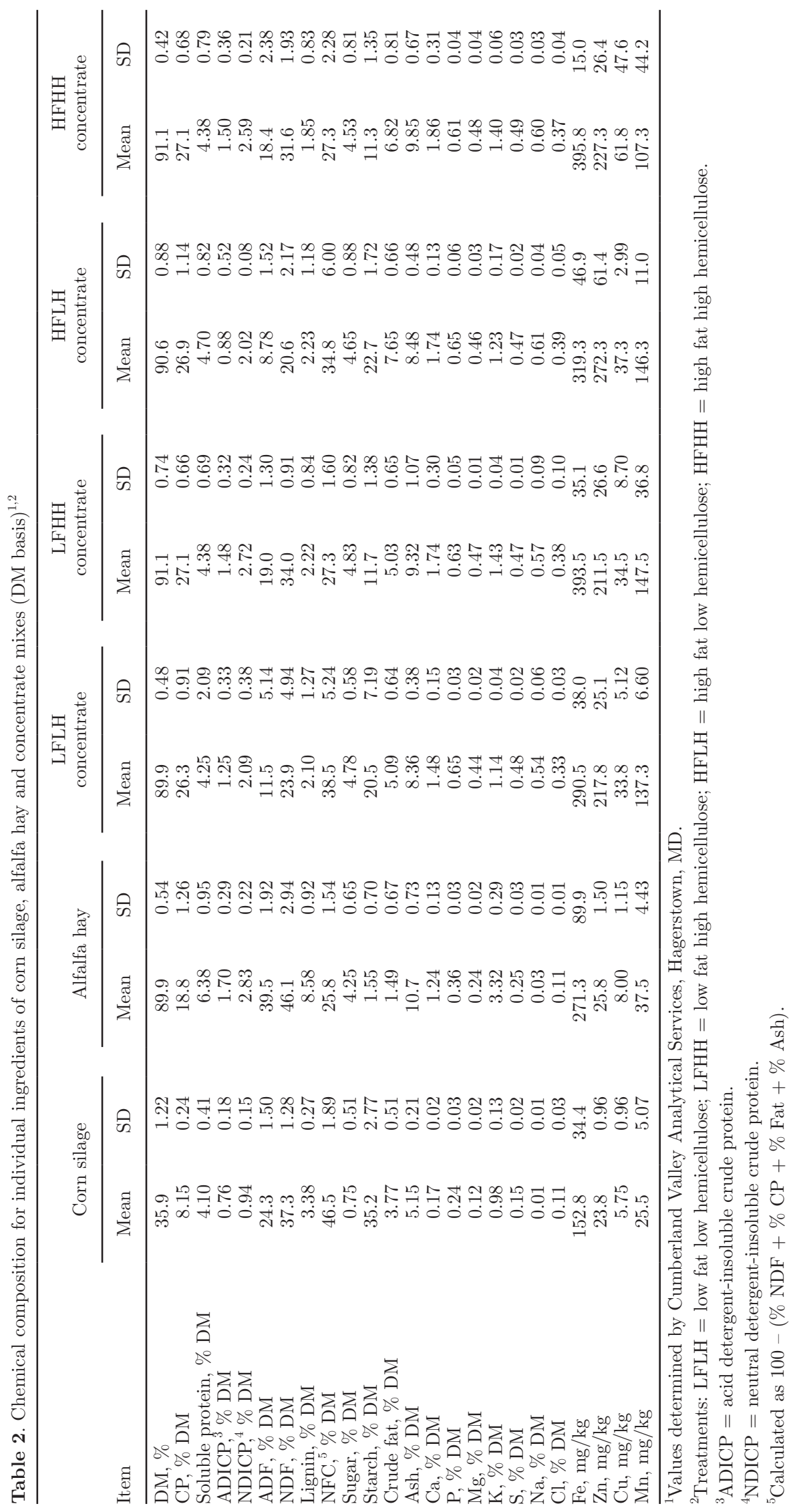


Table 3. Particle distribution of treatments differing in fat and hemicellulose concentration based on the $\mathrm{TMR}^{1}$

\begin{tabular}{|c|c|c|c|c|c|c|c|c|}
\hline Particle size $^{2}$ & \multicolumn{2}{|c|}{ LFLH } & \multicolumn{2}{|c|}{ LFHH } & \multicolumn{2}{|c|}{ HFLH } & \multicolumn{2}{|c|}{ HFHH } \\
\hline$>19.0 \mathrm{~mm}$ & 4.38 & 1.92 & 3.88 & 0.83 & 3.75 & 2.19 & 2.63 & 1.30 \\
\hline $1.18-8.0 \mathrm{~mm}$ & 64.0 & 2.14 & 55.6 & 6.97 & 63.8 & 2.82 & 56.6 & 7.48 \\
\hline$<1.18 \mathrm{~mm}$ & 11.1 & 5.22 & 6.13 & 3.76 & 13.3 & 3.54 & 6.00 & 3.78 \\
\hline
\end{tabular}

${ }^{1}$ Treatments: LFLH = low fat low hemicellulose; LFHH = low fat high hemicellulose; HFLH = high fat low hemicellulose; HFHH $=$ high fat high hemicellulose.

${ }^{2}$ Determined using the Penn State particle separator on a wet basis (Heinrichs and Kononoff, 2002).

mid-lactation Holstein cows. Both of these results agree with observations from the current study. The effects of fat supplementation on milk production and milk components are variable and depend on many factors, such as fat source, amount of fat, stage of lactation, and composition of the diet (Knapp et al., 2014). Inclusion of fat tended $(P=0.11)$ to reduced milk fat from 5.91 to $5.56 \pm 0.35 \%$, whereas hemicellulose had no effect $(P=0.31)$. Milk fat yield tended $(P=0.11)$ to be reduced with the inclusion of fat from 1.36 to 1.26 $\pm 0.13 \mathrm{~kg} / \mathrm{d}$, whereas hemicellulose had no effect $(P$ $=0.54)$. As the concentration of UFA increase in the diet of lactating cows, it is generally believed to also increase the chance of milk fat depression resulting in a lower milk fat percentage.

We have previously observed milk fat depression when corn oil is fed to cows consuming diets containing
DDGS (Ramirez-Ramirez et al., 2015) and is likely a result of increased rumen production of bioactive isomers which are known to suppress mammary uptake and de novo synthesis of FA. The inclusion of fat tended $(P=$ $0.15)$ to reduce milk protein from 3.47 to $3.39 \pm 0.13 \%$ while hemicellulose had no effect $(P=0.95)$. Neither fat nor hemicellulose affected milk protein yield $(P \geq$ 0.30 ) averaging $0.78 \pm 0.06 \mathrm{~kg} / \mathrm{d}$ across all treatments. In a recently conducted meta-analysis, milk protein percentage was observed to decrease with inclusion of tallow while milk protein yield was not affected by inclusion of tallow (Rabiee et al., 2012). These investigators hypothesized that when fat supplementation negatively affects milk protein the response may be due to interactions with several factors including glucose availability, insulin resistance, and efficiency of milk production.

Table 4. Dry matter intake, milk production and components, BW, BCS, and water intake of treatments differing in fat and hemicellulose concentration

\begin{tabular}{|c|c|c|c|c|c|c|c|c|}
\hline Item & \multicolumn{4}{|c|}{ Treatment $^{1}$} & $\mathrm{SEM}^{2}$ & \multicolumn{3}{|c|}{$P$-value ${ }^{3}$} \\
\hline Milk yield, $\mathrm{kg} / \mathrm{d}$ & 23.0 & 23.4 & 23.1 & 22.3 & 1.72 & 0.51 & 0.78 & 0.40 \\
\hline $\mathrm{ECM},{ }^{4} \mathrm{~kg} / \mathrm{d}$ & 30.4 & 31.5 & 29.5 & 28.9 & 2.41 & 0.15 & 0.80 & 0.46 \\
\hline Fat, $\%$ & 5.78 & 6.04 & 5.48 & 5.64 & 0.35 & 0.11 & 0.31 & 0.81 \\
\hline Fat yield, $\mathrm{kg} / \mathrm{d}$ & 1.32 & 1.40 & 1.26 & 1.26 & 0.13 & 0.11 & 0.54 & 0.50 \\
\hline Lactose, $\%$ & 4.81 & 4.80 & 4.80 & 4.82 & 0.04 & 0.90 & 0.91 & 0.64 \\
\hline MUN, mg/dL & 22.1 & 20.8 & 21.6 & 20.0 & 0.97 & 0.22 & 0.03 & 0.77 \\
\hline $\mathrm{SCC}$, cells $/ \mathrm{mL}$ & 74.9 & 90.5 & 288.9 & 63.1 & 86.4 & 0.31 & 0.30 & 0.21 \\
\hline Body weight, $\mathrm{kg}$ & 442.1 & 447.2 & 447.0 & 447.5 & 19.9 & 0.68 & 0.67 & 0.71 \\
\hline $\mathrm{BCS}^{5}$ & 3.30 & 3.31 & 3.40 & 3.38 & 0.14 & 0.28 & 0.97 & 0.82 \\
\hline Free water intake, $\mathrm{L} / \mathrm{d}$ & 79.2 & 69.8 & 75.5 & 63.5 & 5.45 & 0.25 & 0.03 & 0.75 \\
\hline Water intake from feed, $\mathrm{L} / \mathrm{d}$ & 5.60 & 7.85 & 5.61 & 7.33 & 0.49 & 0.33 & $<0.01$ & 0.30 \\
\hline
\end{tabular}

\footnotetext{
${ }^{1}$ Treatments: $\mathrm{LFLH}=$ low fat low hemicellulose; $\mathrm{LFHH}=$ low fat high hemicellulose; HFLH $=$ high fat low hemicellulose; HFHH $=$ high fat high hemicellulose.

${ }^{2}$ Lowest standard error of treatment means is shown.

${ }^{3} \mathrm{~F}=$ main effect of fat inclusion, $\mathrm{H}=$ main effect of hemicellulose concentration, $\mathrm{I}$ = interaction between fat and hemicellulose.

${ }^{4}$ Calculated as $0.327 \times$ milk yield $(\mathrm{kg})+12.95 \times$ fat $(\mathrm{kg})+7.20 \times$ protein $(\mathrm{kg})$, adjusted for $3.5 \%$ fat and $3.2 \%$ total protein $(\mathrm{DHI}$ Glossary, DRMS, 2014).

${ }^{5} 1-5$ according to Wildman et al. (1982).
} 
Table 5. Daily consumption of oxygen and production of carbon dioxide and methane for treatments differing in fat and hemicellulose concentration

\begin{tabular}{|c|c|c|c|c|c|c|c|c|}
\hline \multirow[b]{2}{*}{ Item } & \multicolumn{4}{|c|}{ Treatment $^{1}$} & \multirow[b]{2}{*}{$\mathrm{SEM}^{2}$} & \multicolumn{3}{|c|}{$P$-value ${ }^{3}$} \\
\hline & LFLH & LFHH & HFLH & HFHH & & $\mathrm{F}$ & $\mathrm{H}$ & I \\
\hline $\mathrm{CO}_{2}$ production, L/d & $4,663.6$ & $4,717.4$ & $4,529.2$ & $4,492.7$ & 254.6 & 0.24 & 0.95 & 0.75 \\
\hline $\mathrm{CH}_{4}$ production, $\mathrm{L} / \mathrm{d}$ & 393.0 & 396.4 & 364.7 & 371.9 & 26.8 & 0.20 & 0.79 & 0.92 \\
\hline $\mathrm{RQ},{ }^{4} \mathrm{~L} / \mathrm{L}$ & 1.03 & 1.04 & 1.01 & 1.03 & 0.01 & $<0.01$ & 0.08 & 0.72 \\
\hline Milk produced $/ \mathrm{CH}_{4}, \mathrm{~kg} / \mathrm{L}$ & 0.059 & 0.055 & 0.065 & 0.061 & 0.004 & 0.03 & 0.17 & 0.88 \\
\hline Heat production, ${ }^{5}$ Mcal & 22.5 & 22.5 & 21.8 & 21.7 & 1.17 & 0.29 & 0.92 & 0.90 \\
\hline Heat production, kcal $/$ metabolic BW & 244.1 & 244.0 & 235.3 & 232.8 & 10.1 & 0.06 & 0.79 & 0.78 \\
\hline
\end{tabular}

${ }^{1}$ Treatments: $\mathrm{LFLH}=$ low fat low hemicellulose; LFHH $=$ low fat high hemicellulose; HFLH $=$ high fat low hemicellulose; HFHH $=$ high fat high hemicellulose.

${ }^{2}$ Lowest standard error of treatment means is shown.

${ }^{3} \mathrm{~F}=$ main effect of fat inclusion, $\mathrm{H}=$ main effect of hemicellulose concentration, $\mathrm{I}=$ interaction between fat and hemicellulose.

${ }^{4} \mathrm{RQ}=$ respiratory quotient, $\mathrm{CO}_{2}$ production $/ \mathrm{O}_{2}$ consumption.

${ }^{5}$ Heat production (HP) calculated with Brouwer (1965) equation from oxygen consumption (L), carbon dioxide production (L), methane production $(\mathrm{L})$ and urine $-\mathrm{N}(\mathrm{g})\left(\mathrm{HP}=3.866 \times \mathrm{O}_{2}+1.200 \times \mathrm{CO}_{2}-0.518 \times \mathrm{CH}_{4}-1.431 \times \mathrm{N}\right)$.

In the case of free water intake, fat was not observed to have an effect $(P=0.25)$, whereas increasing hemicellulose concentration reduced $(P=0.03)$ free water intake from 77.4 to $66.7 \pm 5.45 \mathrm{~L} / \mathrm{d}$. In comparison, water intake from feed was not affected by fat $(P=$ $0.33)$, whereas increasing hemicellulose concentration increased $(P<0.01)$ water intake from feed from 5.61 to $7.59 \pm 0.49 \mathrm{~L} / \mathrm{d}$. For total water intake, fat had no effect $(P=0.24)$, whereas increasing hemicellulose concentration tended to reduce $(P=0.07)$ total water intake from 83.0 to $74.3 \pm 5.70 \mathrm{~L} /$ d. Diets with increasing hemicellulose concentration had a higher proportion $(44.1 \% \mathrm{DM})$ of corn silage and lower diet DM (54.2\%) compared with the diets with decreasing hemicellulose concentration $(24.7 \%$ DM of corn silage and diet DM 64.8\%). Therefore, increasing hemicellulose concentration of diets lowered diet DM, reduced free water intake and total water intake, and increased water intake from feed due to the higher inclusion of a wetter ingredient (corn silage). The adjustment of free water intake due to differences in diet DM concentrations has been observed by others; for example, Kume et al. (2010) observed that free water intake increased and feed water intake decreased as diet DM increased with cows eating higher forage diets.

\section{Gas Consumption and Production}

Gas consumption and production is listed in Table 5 . No interactions $(P \geq 0.40)$ were observed between fat and hemicellulose for any dependent variable tested. Oxygen consumption was not affected $(P \geq 0.40)$ by treatments, averaging $4,459.4 \pm 232.4 \mathrm{~L} / \mathrm{d}$ across all treatments. Carbon dioxide production was not af- fected $(P \geq 0.24)$ by treatments, averaging 4,600.7 \pm $254.6 \mathrm{~L} / \mathrm{d}$ across all treatments. This was is not surprising, as DMI was not different and DMI and $\mathrm{CO}_{2}$ production are correlated because $\mathrm{CO}_{2}$ is a by-product of ruminal fermentation. Methane production was not affected $(P \geq 0.20)$ by treatments, averaging $381.5 \pm$ $26.8 \mathrm{~L} / \mathrm{d}$ across all treatments. Hales et al. (2017) reported a linear decrease in methane production as corn oil increased in the diet from 0 to $6 \%$ of diet DM. Furthermore, Johnson and Johnson (1995) suggested that cattle fed supplemental fat, such as tallow, had reduced methane production compared with control diets. It is also generally expected that the fermentation of fibrous carbohydrates results in greater methane production than NFC (Ribeiro et al., 2014). Therefore, we expected that greater fat inclusion would have affected total methane production, yet this was not observed in the current study.

Methane per unit of DMI tended $(P=0.12)$ to be reduced with the inclusion of fat, from 24.9 to 23.1 $\pm 1.59 \mathrm{~L} / \mathrm{kg}$, whereas hemicellulose had no effect $(P$ $=0.48)$. Beauchemin et al. (2007) found that when diets included tallow, methane produced per unit of DMI was significantly reduced by $11 \%$. In the current study, tallow tended to reduce methane produced per unit of DMI by $9 \%$. Milk produced per unit of methane was increased $(P=0.03)$ with the inclusion of fat from 0.057 to $0.063 \pm 0.004 \mathrm{~kg} / \mathrm{L}$, whereas hemicellulose had no effect $(P=0.17)$. Johnson et al. (2002) observed that supplementation of oilseeds did not affect methane production, but tended to increase milk produced per unit of methane. The fat source was different in the current study but produced similar results as that reported by Johnson et al. (2002). 
The respiratory quotient $(\mathbf{R Q})$, the ratio of $\mathrm{CO}_{2}$ produced and $\mathrm{O}_{2}$ consumed, was reduced $(P<0.01)$ with the inclusion of fat, from 1.04 to $1.02 \pm 0.01$ $\mathrm{L} / \mathrm{L}$, whereas increasing hemicellulose concentration tended $(P=0.08)$ to increase RQ, from 1.02 to 1.04 $\mathrm{L} / \mathrm{L}$. Although full explanation of these effects are not obvious, it is well known that the changes in pathways for ATP production may be associated with changes in RQ. For example, when carbohydrates are the main fuel, the RQ is close to 1.0; in comparison, when fat is the main fuel, the RQ is 0.7 (Blaxter, 1967; Ketelaars and Tolkamp, 1996). Additionally, when used as the main fuel, acetate results in an RQ of 1.0, followed by propionate (0.86) and butyrate (0.80) (Cherepanov and Agaphonov, 2010). Thus, the increase of hemicellulose on increasing RQ may be due differences in rumen fermentation and end-products of fermentation.

Heat production was not affected $(P \geq 0.29)$ by treatments, averaging $22.1 \pm 1.17 \mathrm{Mcal} / \mathrm{d}$ across all treatments. Heat produced per metabolic BW tended $(P=0.06)$ to be reduced with the inclusion of fat, from 244.1 to $234.1 \pm 10.1 \mathrm{~d} / \mathrm{MBW}$, whereas hemicellulose had no effect $(P=0.79)$. The addition of fat and reduction in HP may have been due to a reduction in heat produced from fermentation, but such effects are often observed in both ruminants and nonruminants (Moallem et al., 2010; Pettigrew and Moser, 1991). It is more likely that the reduction in HP from the addition of fat are observed because of reductions in DMI, which was also observed in the current study.

\section{Energy Partitioning}

Energy partitioning estimates are listed in Table 6 . Tendencies for interactions $(P \leq 0.12)$ were observed between fat and hemicellulose for net energy balance (milk plus tissue energy; Mcal/d), ME (Mcal/kg of $\mathrm{DM}$ ), and net energy balance (Mcal/kg of DM). The total intake of net energy balance was lowest for LFLH diet $(16.3 \mathrm{Mcal} / \mathrm{d})$; this diet had the least digestible fiber and the least fat (Table 1). Both fat and fiber will supply energy but, because these diets had the least amount of both, less energy will be supplied compared with the other treatments. This treatment also had the most negative tissue energy because the cows were at a negative energy balance when fed this diet. For net energy balance (Mcal/d), an interaction was observed $(P=0.12)$. Increasing hemicellulose in low-fat diets

Table 6. Energy partitioning of treatments differing in fat and hemicellulose concentration

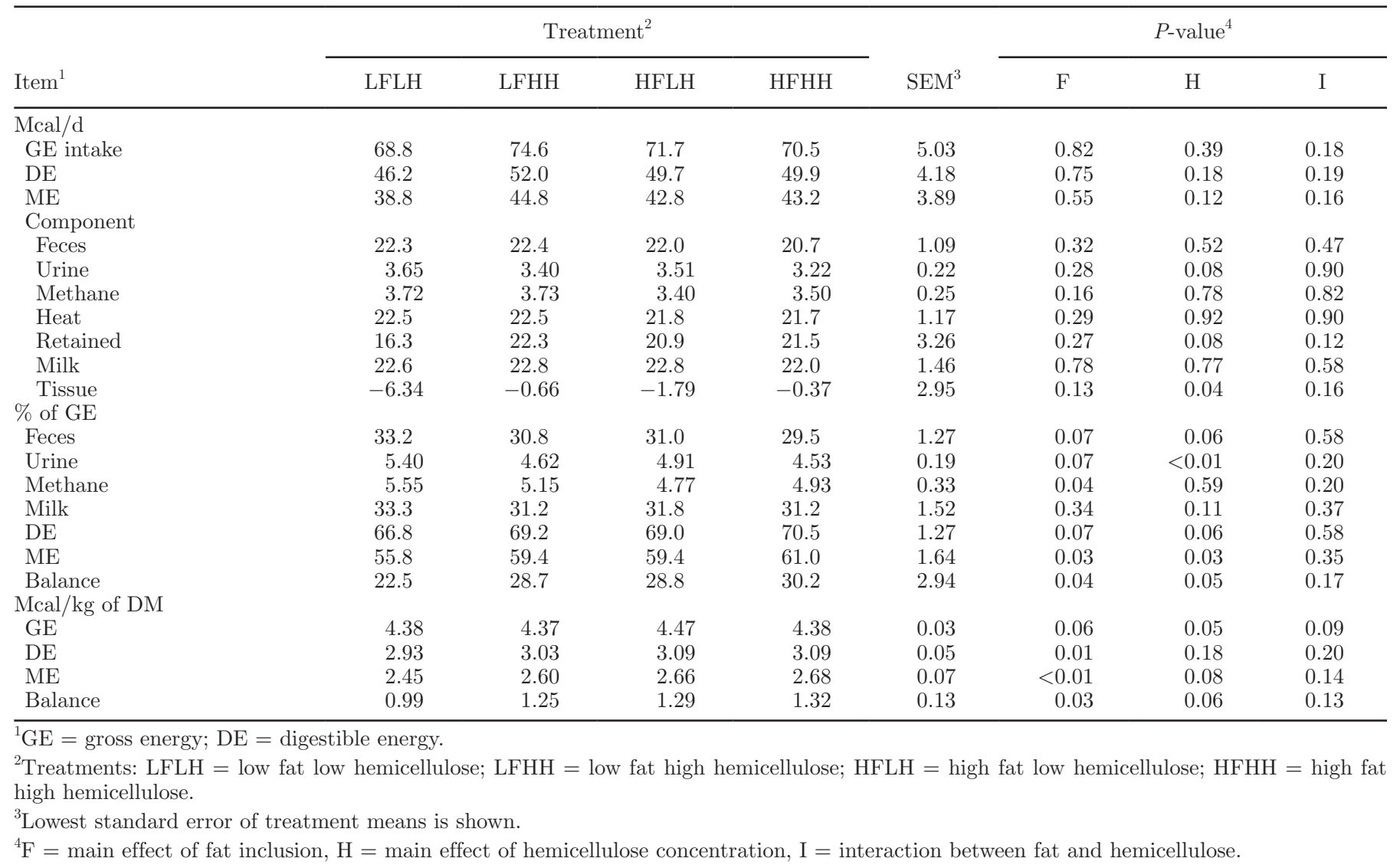


tended ( $P=0.12)$ to increase net energy balance, but this was not observed in high-fat diets.

Energy lost in feces was not affected $(P \geq 0.32)$ by treatments, averaging $21.9 \pm 1.09 \mathrm{Mcal} / \mathrm{d}$. Whereas energy lost as urine tended $(P=0.08)$ to be reduced, from 3.58 to $3.31 \pm 0.22 \mathrm{Mcal} / \mathrm{d}$, by increasing hemicellulose concentration, whereas fat inclusion had no effect $(P=0.28)$. Energy lost as methane was not affected $(P$ $\geq 0.16$ ) by treatments, averaging $3.59 \pm 0.25 \mathrm{Mcal} / \mathrm{d}$. An interaction was observed with hemicellulose in lowfat diets tending $(P=0.12)$ to increase RE, but this was not observed in high-fat diets. Milk energy was not affected $(P \geq 0.58)$ by fat or hemicellulose. Tissue energy tended $(P=0.13)$ to increase with the inclusion of fat, from -3.5 to $-1.08 \pm 2.95 \mathrm{Mcal} / \mathrm{d}$, whereas increasing hemicellulose concentration increased $(P=$ $0.04) \mathrm{TE}$ from -4.07 to $-0.52 \pm 2.95 \mathrm{Mcal} / \mathrm{d}$. This was likely caused by fat and fiber being used as energy sources and therefore resulting in greater TE and less mobilization of recovered energy in the form of tissue.

Methane production, when expressed as a percent of GE, was reduced $(P=0.04)$ with the inclusion of fat from 5.35 to $4.85 \pm 0.33 \%$ of the diet, whereas hemicellulose had no effect $(P=0.59)$ on methane production as a proportion of GE. Using Angus beef heifers, Beauchemin et al. (2007) observed that tallow reduced methane production as a percent of GE by 15\%. Additionally, Hales et al. (2017) noted that methane production as a percent of GE intake decreased in the diet as fat increased from 0 to $6 \%$ of DM. In the current study, methane as percent of GE was reduced by $11 \%$. The addition of dietary fat through 3 mechanisms: by providing a hydrogen sink through biohydrogenation, feeding ingredients that increase propionate production, and replacing less fermentable substrates with more fermentable dietary substrates (Hales et al., 2017). In the current study, the mode of action of methane reduction was likely by replacing a less-fermentable substrate with an ingredient that is more fermentable.

Net energy balance, when expressed as a percent of GE, was increased $(P=0.04)$ with the inclusion of fat, from 25.6 to $29.5 \pm 2.94 \%$, whereas increasing hemicellulose concentration also increased $(P=0.05)$ net energy balance from 25.7 to $29.5 \pm 2.94 \%$. Finally, when expressing net energy balance as Mcal $/ \mathrm{kg}$ of DM an interaction was observed. Specifically, increasing hemicellulose in low-fat diets tended $(P=0.13)$ to increase net energy balance, but this was not observed in high-fat diets. It is important to note that little research has been done looking at both fat and fiber and, consequently, the interaction between them on energy partitioning in lactating dairy cattle. More research in this area may shed light on practical methods of diet formulation to reduce methane production in lactating dairy cattle.

Maintenance energy requirements were calculated through regression of $\mathrm{ME}$ intake and $\mathrm{RE}$ and solving for ME intake when RE equals zero, as illustrated in Figure 1 (Foth et al., 2015). Maintenance was calculated to be $188 \mathrm{kcal} / \mathrm{MBW}$ with an efficiency of ME use for lactation $\left(\boldsymbol{k}_{1}\right)$ of 0.84 . Observations in the current study were greater than some of the previous estimates of maintenance energy requirements and efficiencies of lactation for lactating dairy cows. Previous published maintenance energy requirements in lactating dairy cows were $134.1 \pm 25.7 \mathrm{kcal} / \mathrm{MBW}$ (Moe and Tyrrell, 1971; Vermorel et al., 1982; Birkelo et al., 2004; Xue et al., 2011; Foth, 2014). Foth et al. (2015) reported a maintenance estimate of $208 \mathrm{Mcal} / \mathrm{MBW}$ and $k_{1}$ of 0.76 in lactating Holstein and Jersey cows. Comparably, Yan et al. (1997) reported maintenance estimates for lactating Holstein-Friesian cows ranging from 146 to $179 \mathrm{kcal} / \mathrm{MBW}$, with a mean of $160 \mathrm{kcal} / \mathrm{MBW}$, and found the $k_{1}$ to range from 0.61 to 0.68 . Furthermore, Blaxter (1967) found $k_{1}$ to be about 0.70 and Blaxter (1989) found the $k_{1}$ to be around 0.65 . Over 7 lactation balance trials, Coppock et al. (1964) reported the efficiency of conversion of ME to milk estimates ranged from 63 to $107 \%$, with a mean of $75.5 \%$. The mean of the current study, $84 \%$, agrees with that of Coppock et al. (1964). In the current study, greater values for maintenance requirements and $k_{1}$ were determined than the Yan et al. (1997) study, suggesting greater maintenance energy requirements and greater efficiency of converting ME to milk; this may be because of the added dietary fat used in the present study. As compared with Foth et al. (2015), the maintenance requirements were lesser, whereas a greater efficiency of ME use for lactation was observed in the current study. This potentially suggests that the greater conversion efficiency of ME use for lactation results in decreased maintenance requirements because more energy is being partitioned toward lactation; consequently, it is reasonable to accept the maintenance estimates of the current study (188 kcal/ MBW). The previous studies were all a mix of Holstein and Jersey cows, and in the current study Jersey cows were used. These data suggests that the maintenance requirements of Jersey cows are not lower than Holsteins cows.

\section{Nitrogen Balance}

The partitioning of nitrogen is listed in Table 7. Interactions $(P \leq 0.12)$ were observed between fat and hemicellulose for urine $\mathrm{N}$ as a percent of $\mathrm{N}$ intake and $\mathrm{N}$ balance as a percent of $\mathrm{N}$ intake. Total $\mathrm{N}$ balance 
Table 7. Nitrogen partitioning of treatments differing in fat and hemicellulose concentration

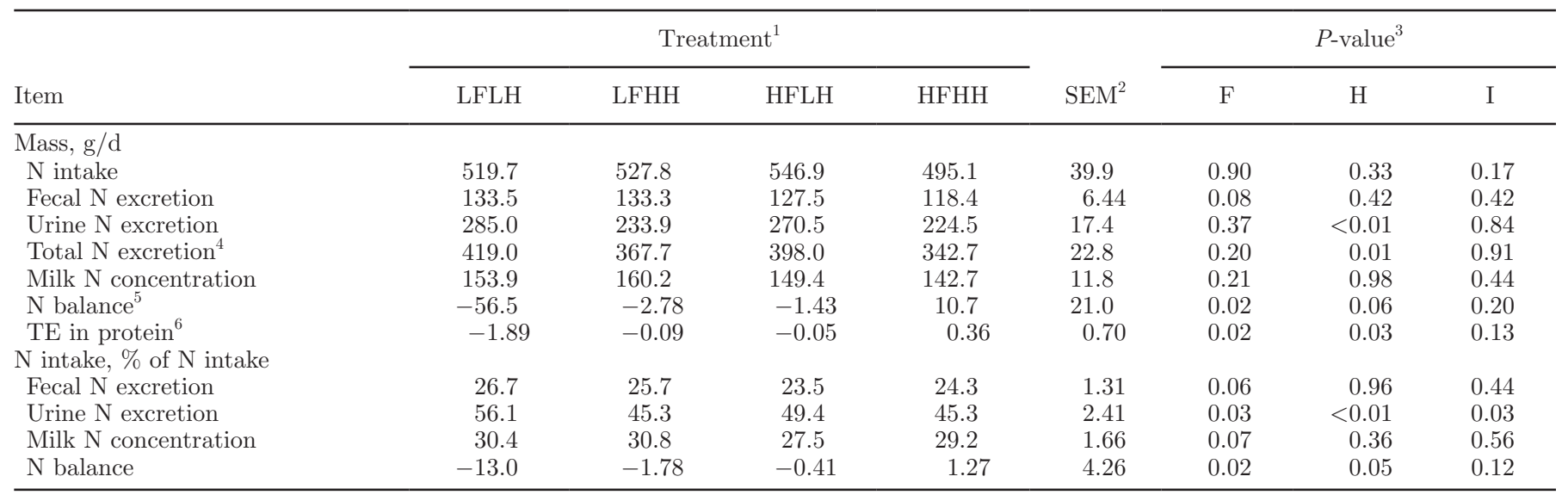

${ }^{1}$ Treatments: LFLH = low fat low hemicellulose; LFHH = low fat high hemicellulose; HFLH $=$ high fat low hemicellulose; HFHH $=$ high fat high hemicellulose.

${ }^{2}$ Lowest standard error of treatment means is shown.

${ }^{3} \mathrm{~F}=$ main effect of fat inclusion, $\mathrm{H}=$ main effect of hemicellulose concentration, $\mathrm{I}=$ interaction between fat and hemicellulose.

${ }^{4}$ Fecal $\mathrm{N}+$ urine $\mathrm{N}$.

${ }^{5}$ Nitrogen balance $=$ intake $\mathrm{N}-$ fecal $\mathrm{N}-$ urine $\mathrm{N}-$ milk $\mathrm{N}$.

${ }^{6} \mathrm{TE}=$ tissue energy.

expressed as total mass or as a proportion of $\mathrm{N}$ intake was increased when increasing the fat and hemicellulose content of the diet. Nitrogen balance was lesser in diets containing the lowest concentration of fat and hemicellulose and was in a negative balance $(-56.5 \mathrm{~g} / \mathrm{d} ; P$ $=0.02)$. This is likely because the LFLH treatment contained the lowest concentration of energy (0.98 Mcal $/ \mathrm{kg}$ ) and, when consuming this treatment, cows mobilized large proportions of tissue stores to meet the energetic demands of lactation and excreted catabolized protein as urea in the urine (Maltz and Silanikove, 1996). Dietary factors can have an effect on the amount and route of $\mathrm{N}$ excretion (i.e., fecal or urinary $\mathrm{N}$; Weiss et al., 2009). In the current study, the LFLH diet resulted in the most $\mathrm{N}$ excretion $(\mathrm{g} / \mathrm{d})$ and urine $\mathrm{N}(\mathrm{g} / \mathrm{d}$ and $\%$ of $\mathrm{N}$ intake). These observations may suggest the cows were excreting the excess $\mathrm{N}$ mostly through urinary routes.

Total urine nitrogen $(\mathrm{g} / \mathrm{d})$ was reduced $(P<0.01)$ with increasing hemicellulose concentration from 277.8 to $229.2 \pm 17.4 \mathrm{~g} / \mathrm{d}$ for low-hemicellulose and high-hemicellulose diets, respectively. Likewise, MUN concentration was reduced, suggesting greater absorption of $\mathrm{N}$ in the hind gut from increased hemicellulose; therefore, less $\mathrm{N}$ was lost via the mammary glands and excreted as urine. When expressing urine $\mathrm{N}$ as a percent of $\mathrm{N}$ intake, an interaction was observed $(P$ $=0.03$ ). Increasing fat in low-hemicellulose diets reduced $(P=0.03)$ urine $\mathrm{N}$, but this was not observed in high-hemicellulose diets. Total $\mathrm{N}$ balance $(\mathrm{g} / \mathrm{d}$; intake $\mathrm{N}$ minus fecal, urinary, and milk $\mathrm{N})$ was improved $(P$
$=0.02)$ with inclusion of fat from -26.7 to $4.64 \pm$ $21.0 \mathrm{~g} / \mathrm{d}$, whereas increasing hemicellulose tended $(P$ $=0.06$ ) to improve $\mathrm{N}$ balance from -28.0 to $3.96 \pm$ $21.0 \mathrm{~g} / \mathrm{d}$. We also observed an interaction $(P=0.12)$ for $\mathrm{N}$ balance expressed as percent of $\mathrm{N}$ intake. Increasing fat in low-hemicellulose diets tended $(P=0.12)$ to improve $\mathrm{N}$ balance, but this was not observed in high-hemicellulose diets. From these observations, it could be concluded that the inclusion of fat improves $\mathrm{N}$ utilization.

\section{Nutrient Digestibility}

Apparent digestibility of the diets are listed in Table 8. No interactions $(P \geq 0.31)$ were observed between fat and hemicellulose for any dependent variable tested. Dry matter digestibility increased $(P=0.05)$ with increasing hemicellulose concentrations, from 68.0 to 69.9 $\pm 1.30 \%$, whereas fat had no effect $(P=0.18)$. Comparably, Herrick et al. (2012) observed no difference in DM digestibility. Organic matter digestibility increased $(P=0.05)$ with increasing hemicellulose concentration, from 70.0 to $71.9 \pm 1.23 \%$, whereas the inclusion of fat tended $(P=0.10)$ to increase digestibility from 70.2 to $71.7 \pm 1.23 \%$. Crude protein digestibility increased $(P$ $=0.02$ ) with the inclusion of fat, from 73.8 to $77.2 \pm$ $1.62 \%$, whereas hemicellulose had no effect $(P=0.55)$. Previous research by Simas et al. (1997) also showed increased CP digestibility with the inclusion of fat; however, those authors could not deduce the reason for this observation. Increased digestibility is likely due to 
Table 8. Apparent digestibility of treatments differing in fat and hemicellulose concentration

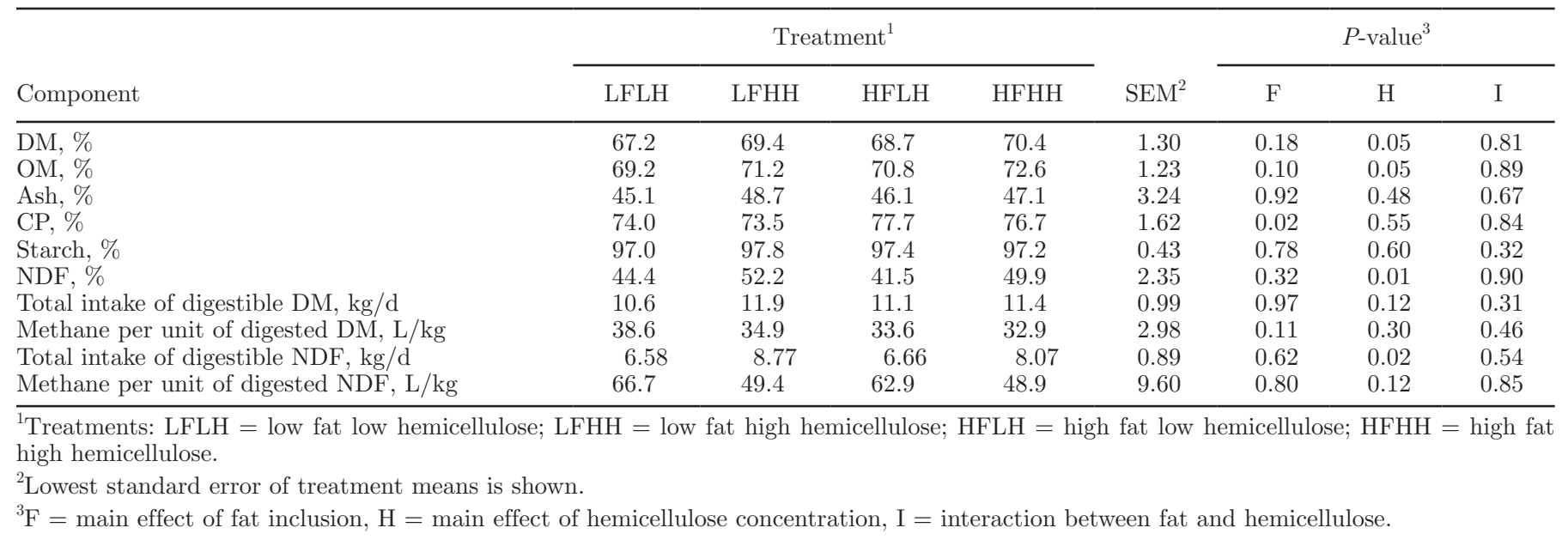

increased energy available for protein digestion. Starch digestibility was not affected $(P \geq 0.60)$ by treatments, averaging $97.4 \pm 0.43 \%$ across all treatments.

Neutral detergent fiber digestibility increased $(P=$ 0.01 ) with increasing hemicellulose concentration, from 43.0 to $51.1 \pm 2.35 \%$, whereas fat had no effect $(P=$ 0.32 ) on NDF digestibility. The increase in NDF digestibility by increasing hemicellulose in diets may be due to the composition of NDF and lack of lignification. Herrick et al. (2012) observed a significant increase in NDF digestibility (48.1\%) when a hemicellulose extract was fed. Although the addition of fat to the diet can reduce methane production, it can also reduce fiber digestibility by reducing the activity of the fibrolytic microbes (Beauchemin et al., 2007), such as Fibrobacter succinogenes or Ruminococcus albus. Huhtanen et al. (2009) observed reduced fiber digestibility with increasing concentrations of fat. Surprisingly, in the current study a reduction in fiber digestibility due to fat was not observed. This may be because the fat supplementation was not great enough to have negative effects and the total fat content of the diets used was less than $7 \%$. Generally, lactating cow rations include 4 to $5 \%$ crude fat with fat supplementation of up to 5 to $7 \%$ of DM. Current recommendations for dairy cows (NRC, 2001) in most field conditions are that the diet concentration of fat should not exceed 6 to $7 \%$ DM.

Methane emissions can also be related to nutrient digestibility. Increasing hemicellulose concentrations tended $(P=0.12)$ to increase total intake of digestible $\mathrm{DM}$, from 10.9 to $11.7 \pm 0.99 \mathrm{~kg} / \mathrm{d}$, whereas fat had no effect $(P=0.97)$. Methane per unit of digested DM tended $(P=0.11)$ to decrease with the inclusion of fat, from 36.8 to $33.3 \pm 2.98 \mathrm{~L} / \mathrm{kg}$, whereas hemicellulose had no effect $(P=0.30)$. When cattle consume fibrous by-products, such as DDGS, it is believed to result in less methane per unit of digested DM, possibly because these feeds are high in hemicellulose, which is more digestible than cellulose or lignin (Johnson and Johnson, 1995; Knapp et al., 2014). An explanation for this effect is not fully understood, but may be related to differences in biochemical metabolism of 5- and 6-carbon sugars. Furthermore, Knapp et al. (2014) suggested that these differences may also affect the community structure and function of microbial species that degrade and ferment the substrate and also produce methane. Total intake of digestible NDF increased $(P=$ 0.02 ) with increasing hemicellulose concentration, from 6.62 to $8.42 \pm 0.89 \mathrm{~kg} / \mathrm{d}$, whereas fat had no effect $(P$ $=0.62)$. Methane per unit of digested NDF tended to $(P=0.12)$ decrease with increasing hemicellulose concentration, from 64.8 to $49.2 \pm 9.60 \mathrm{~L} / \mathrm{kg}$, whereas fat had no effect $(P=0.80)$. The reduction in methane per unit of digested NDF is an important result because it shows that utilization of type and even maturity of forage may reduce methane production, and that it is possible to adjust the ingredients included in the diet to affect methane production.

\section{CONCLUSIONS}

Total volume of methane production was not affected by fat or hemicellulose concentration in the diet, but when expressed as volume per unit of DMI, fat tended to decrease methane production. Increasing hemicellulose concentration tended to reduce methane per unit of digestible NDF while improving NDF digestibility. Net energy balance for dairy cows is improved by increasing hemicellulose in diets containing lower amounts of fat. These results suggest that manipulations of dietary ingredients can improve energy utilizations in lactating dairy cattle. 


\section{ACKNOWLEDGMENTS}

A portion of this work was funded by funds made available by The Nebraska Corn Board (Lincoln, NE) and The Nebraska Environmental Trust (Lincoln, NE).

\section{REFERENCES}

AOAC International. 2000. Official Methods of Analysis. 17th ed. AOAC Int., Gaithersburg, MD.

AOAC International. 2006. Official Methods of Analysis. 18th ed. AOAC Int., Gaithersburg, MD.

Beauchemin, K. A., M. Kreuzer, F. O'Mara, and T. A. McAllister. 2008. Nutritional management for enteric methane abatement: A review. Aust. J. Exp. Agric. 48:21-27.

Beauchemin, K. A., S. M. McGinn, and H. Petit. 2007. Methane abatement strategies for cattle: Lipid supplementation of diets. Can. J. Anim. Sci. 87:431-440.

Benchaar, C., F. Hassanat, R. Gervais, P. Y. Chouinard, C. Julien, H. V. Petit, and D. I. Massé. 2013. Effects of increasing amounts of corn dried distillers grains with solubles in dairy cow diets on methane production, ruminal fermentation, digestion, $\mathrm{N}$ balance, and milk production. J. Dairy Sci. 96:2413-2427.

Benchaar, C., C. Pomar, and J. Chiquette. 2001. Evaluation of dietary strategies to reduce methane production in ruminants: A modelling approach. Can. J. Anim. Sci. 81:563-574.

Birkelo, C. P., M. J. Brouk, and D. J. Schingoethe. 2004. The energy content of wet corn distillers grains for lactating dairy cows. J. Dairy Sci. 87:1815-1819.

Blaxter, K. 1967. The Energy Metabolism of Ruminants. 2nd ed. Hutchison \& Co. Ltd., London, UK.

Blaxter, K. 1989. Energy Metabolism in Animals and Man. Cambridge University Press, Cmbridge, UK.

Boston, R. C., and D. G. Fox. C. J. Sniffen, R. Janczewski, R. Munsen, and W. Chalupa. 2000. The conversion of a scientific model describing dairy cow nutrition and production to an industry tool: The CPM Dairy project. Pages 361-377 in Modelling Nutrient Utilization in Farm Animals. J. P. McNamara, J. France, and D. Beever, ed. CABI Publishing, Oxford, UK.

Bradford, B. J., and C. R. Mullins. 2012. Invited review: Strategies for promoting productivity and health of dairy cattle by feeding nonforage fiber sources. J. Dairy Sci. 95:4735-4746.

Brouwer, E. 1965. Report of sub-committee on constants and factors Pages 441-443 in Energy Metabolism. K. L. Blaxter, ed. European Association for Animal Production Publication No. 11, Ayr, UK.

Cabezas-Garcia, E. H., S. J. Krizsan, K. J. Shingfield, and P. Huhtanen. 2017. Effects of replacement of late-harvested grass silage and barley with early-harvested silage on milk production and methane emissions. J. Dairy Sci. 100:5228-5240.

Chase, L. E. 2007. Can we feed less starch to our cows? Pages 213-220 in Proc. Cornell Nutr. Conf. for Feed Manufac., Syracuse, NY. Cornell University, Ithaca, NY.

Cherepanov, G. G., and V. I. Agaphonov. 2010. Estimation of substrate-energetic fluxes in lactating cows. J. Anim. Feed Sci. 19:1323.

Coppock, C. E., W. P. Flatt, and L. A. Moore. 1964. Effect of hay to grain ratio on utilization of metabolizable energy for milk production by dairy cows. J. Dairy Sci. 47:1330-1338.

DRMS. 2014. DHI Glossary. Dairy Records Management System., Raleigh, NC.

DuBois, M., K. A. Giles, J. K. Hamiliton, P. A. Rebers, and F. Smith. 1956. Colorimetric method for determination of sugars and related substances. Anal. Chem. 28:350-356.

Foth, A. J. 2014. Energy content of reduced-fat distillers grains and solubles for lactating dairy cows and effects on energy and nitrogen balance. MS Thesis. Department of Animal Science, University of Nebraska, Lincoln.

Foth, A. J., T. Brown-Brandl, K. J. Hanford, P. S. Miller, G. Garcia Gomez, and P. J. Kononoff. 2015. Energy content of reduced-fat dried distillers grains with solubles for lactating dairy cows. J. Dairy Sci. 98:7142-7152.

Freetly, H. C., J. A. Nienaber, and T. Brown-Brandl. 2006. Partitioning of energy during lactation of primiparous beef cows. J. Anim. Sci. 84:2157-2162.

Goering, H. K., and P. J. Van Soest. 1970. Forage Fiber Analysis. USDA Agricultural Research Service. Handbook number 379. U.S. Dept. of Agriculture. Superintendent of Documents, US Government Printing Office, Washington, DC.

Hales, K. E., A. P. Foote, T. M. Brown-Brandl, and H. C. Freetly. 2017. The effects of feeding increasing concentrations of corn oil on energy metabolism and nutrient balance in finishing beef steers. J. Anim. Sci. 95:939-948.

Hall, M. B. 2009. Analysis of starch, including maltooligosaccharides, in animal feeds: a comparison of methods and a recommended method for AOAC collaborative study. J. AOAC Int. 92:42-49.

Heinrichs, A. J., and P. J. Kononoff. 2002. Evaluating particle size of forages and TMRs using the New Penn State Forage Particle Separator. Tech. Bul. DAS 02-42. Pennsylvania State Univ., College Agric. Sci., Cooperative Ext., University Park, PA.

Herrick, K. J., A. R. Hippen, K. F. Kalscheur, J. L. Anderson, S. D. Ranathunga, R. S. Pattion, and M. Abdullah. 2012. Lactation performance and digestibility of forages diets in dairy cows fed a hemicellulose extract. J. Dairy Sci. 95:3342-3353.

Huhtanen, P., M. Rinne, and J. Nousiainen. 2009. A meta-analysis of feed digestion in dairy cows. 2 . The effects of feeding level and diet composition on digestibility. J. Dairy Sci. 92:5031-5042.

Innovation Center for U.S. Dairy. 2014. Dairy Industry Applauds White House Strategy for Methane Emissions Reduction. News Release, March 28, 2014. Accessed Jul. 10, 2017. http://www.nmpf .org/files/White-House-Methane-Emissions-Reduction-032814 .pdf.

Johnson, K. A., and D. E. Johnson. 1995. Methane emissions from cattle. J. Anim. Sci. 73:2483-2492.

Johnson, K. A., R. L. Kincaid, H. H. Westberg, C. T. Gaskins, B. K. Lamb, and J. D. Cronrath. 2002. The effect of oilseeds in diets of lactating cows on milk production and methane emissions. J. Dairy Sci. 85:1509-1515.

Ketelaars, J. J., and B. J. Tolkamp. 1996. Oxygen efficiency and the control of energy flow in animals and humans. J. Anim. Sci. 74:3036-3051.

Knapp, J. R., G. L. Laur, P. A. Vadas, W. P. Weiss, and J. M. Tricarico. 2014. Invited review: Enteric methane in dairy cattle production: Quantifying the opportunities and impact of reducing emissions. J. Dairy Sci. 97:3231-3261.

Kononoff, P. J., and K. J. Hanford. 2006. Technical note: Estimating statistical power of mixed models used in dairy nutrition experiments. J. Dairy Sci. 89:3968-3971.

Kume, S., K. Nonaka, T. Oshita, and T. Kozakai. 2010. Evaluation of drinking water intake, feed water intake and total water intake in dry and lactating cows fed silages. Livest. Sci. 128:46-51.

Maltz, E., and N. Silanikove. 1996. Kidney function and nitrogen balance of high yielding dairy cows at the onest of lactation ${ }^{1}$. J. Dairy Sci. 79:1621-1626.

Moallem, U., G. Altmark, H. Lehrer, and A. Arieli. 2010. Performance of high yielding dairy cows supplemented with fat or concentrate under hot and humid climates. J. Dairy Sci. 93:3192-3202.

Moe, P. W., and H. F. Tyrrell. 1971. Net energy value for lactation of high- and low- protein diets containing corn silage. J. Dairy Sci. 55:288-303.

Moe, P. W., and H. F. Tyrrell. 1979. Methane production in dairy cows. J. Dairy Sci. 62:1583-1586.

NASEM. 2016. Nutrient Requirements of Beef Cattle. 8th rev. ed. Natl. Acad. Press, Washington, DC.

NRC. 2001. Nutrient Requirements of Dairy Cattle. 7th rev. ed. Natl. Acad. Press, Washington, DC.

Nienaber, J. A., and A. L. Maddy. 1985. Temperature controlled multiple chamber indirect calorimeter-design and operation. Trans. ASAE 28:555-560. 
Pettigrew, J. E., and R. L. Moser. 1991. Chapter 8: Fat in swine diets. Pages 189-213 in Swine Nutrition. E. R. Miller, D. E. Ullrey, and A. J. Lewis, ed. Butterworth-Heinemann, Stoneham, MA.

Rabiee, A. R., K. Breinhild, W. Scott, H. M. Golder, E. Block, and I. J. Lean. 2012. Effect of fat additions to diets of dairy cattle on milk production and components: A meta-analysis and metaregression. J. Dairy Sci. 95:3225-3247.

Ramirez Ramirez, H. A., E. Castillo Lopez, K. J. Harvatine, and P. J. Kononoff. 2015. Fat and starch as additive risk factors for milk fat depression in dairy diets containing corn dried distillers grains with solubles. J. Dairy Sci. 98:1903-1914.

Ribeiro, G. O., A. M. Teixeira, F. O. Velasco, E. G. Faria Júnior, L. G. R. Pereira, A. V. Chaves, L. C. Gonçalves, and T. A. McAllister. 2014. Production, nutritional quality and in vitro methane production from Andropogon gayanus grass harvested at different maturities and preserved as hay or silage. Asian-Australas. J. Anim. Sci. 27:330-341.

Simas, J. M., J. T. Huber, C. B. Theurer, K. H. Chen, F. A. P. Santos, and Z. Wu. 1997. Influence of fat sources and sorghum grain treatment on performance and digestibilities of high yielding dairy cows. J. Dairy Sci. 80:2907-2912.

Van Soest, P. J., J. B. Robertson, and B. A. Lewis. 1991. Methods for dietary fiber, neutral detergent fiber, and nonstarch polysaccharides in relation to animal nutrition. J. Dairy Sci. 74:3583-3597.

Vermorel, M., B. Remond, J. Vernet, and D. Liamadis. 1982. Utilization of body reserves by high-producing cows in early lactation; effects of crude protein and amino-acid supply. Pages 18-21 in Energy Metabolism of Farm Animals. A. Ekern and F. Sundstøl, ed. European Association for Animal Production Publication No. 29, Ås, Norway.

Weiss, W. P., L. B. Willett, N. R. St-Pierre, D. C. Borger, T. R. McKelvey, and D. J. Wyatt. 2009. Varying forage type, metabolizable protein concentration, and carbohydrate source affects manure excretion, manure ammonia, and nitrogen metabolism of dairy cows. J. Dairy Sci. 92:5607-5619.

Wildman, E. E., G. M. Jones, P. E. Wagner, R. L. Boman, H. F. Troutt, and T. N. Lesch. 1982. A dairy cow body condition scoring system and its relationship to selected production characteristics. J. Dairy Sci. 65:495-501.

Xue, B., T. Yan, C. F. Ferris, and C. S. Mayne. 2011. Milk production and energy efficiency of Holstein and Jersey-Holstein crossbred dairy cows offered diets containing grass silage. J. Dairy Sci. 94:1455-1464.

Yan, T., F. J. Gordon, R. E. Agnew, M. G. Porter, and D. C. Patterson. 1997. The metabolisable energy requirement for maintenance and the efficiency of utilization of metabolisable energy for lactation by dairy cows offered grass silage-based diets. Livest. Prod. Sci. 51:141-150.

Zebeli, Q., D. Mansmann, B. N. Ametaj, H. Steingass, and W. Drochner. 2010. A model to optimize the requirements of lactating dairy cows for physically effective neutral detergent fibre. Arch. Anim. Nutr. 64:265-278. 